\title{
Two new protist species, Trypanoplasma ojedae sp. n. (Mastigophora: Kinetoplastida) and Trichodina lascrucensis sp. n. (Ciliophora: Peritrichida) in a blenniid fish, Scartichthys viridis, from the coast of Chile
}

\author{
Dos nuevas especies de protista: Trypanoplasma ojedae sp. n. (Mastigophora: Kinetoplastida) \\ y Trichodina lascrucensis sp. n. (Ciliophora: Peritrichida) en un pez \\ blénido Scartichthys viridis, de la costa de Chile \\ Rasul A. Khan', Freddy Díaz ${ }^{2}$ and Mario George-Nascimento² \\ ${ }^{1}$ Department of Biology, Memorial University of Newfoundland, St. John's, NL, Canada \\ ${ }^{2}$ Departamento de Ecología costera, Facultad de Ciencias, Universidad Católica de la Santísima Concepción, \\ Casilla 297, Concepción, Chile \\ mgeorgen@ucsc.cl
}

\begin{abstract}
Resumen.- Dos protistas parásitos fueron observados en un pez blénido, Scartichthys viridis, que habita en pozas de mareas en Las Cruces, Chile central. En la sangre, Trypanoplasma ojedae sp. n. (Mastigophora: Kinetoplastida) se caracteriza por poseer pequeño tamaño $(29,8 \pm 5,0 \times 5,1 \pm 1,2 \mu \mathrm{m})$, un corto flagelo anterior $(4,9 \pm 0,6 \mu \mathrm{m})$, situado anterior al kinetoplasto $(2,4 \pm 0,2)$ y una prominente membrana ondulante. De 18 peces todos estaban infectados y el $67 \%$ se encontraba parasitado en las branquias por una especie de sanguijuela no identificada de la familia Piscicolidae que albergaba estados en desarollo e infectantes del biflagelado. Trichodina lascrucensis sp. n. (Ciliophora: Peritrichida) parasita los filamentos branquiales de todos los peces. El ciliado se caracteriza por su tamaño corporal $(70,8 \pm 8,4 \mu \mathrm{m})$, disco adhesivo $(53 \pm 5,4 \mu \mathrm{m})$, anillo denticular $(33 \pm 3,1 \mu \mathrm{m})$, número promedio de dentículos $(32,8$ $\pm 3,0)$, número promedio de pins $(9,5 \pm 1,0)$ forma de los dentículos y micronúcleos ovoides localizados cerca del armamento macronuclear. Debido a que ninguno de los dos parásitos es similar a cualquier especie descrita para hábitats de pozas de mareas del Océano Pacífico, ambas son consideradas nuevas especies con las características descritas acá.
\end{abstract}

Palabras clave: Peces intermareales, hemoparásito, ciliado branquial, Pacífico sureste

\section{Introduction}

A few studies account for the records and descriptions of protistan parasites in autochtonous marine animals off Chile (Moser \& Noble 1976, Oliva 1982, Morillas et al. 1987, Castro \& Burgos 1996, Khan et al. 2001, Díaz \& George-Nascimento 2003, George-Nascimento et al. 2004, Ibáñez et al. 2005, Pardo-Gandarillas et al. 2004, 2007). Only one trypanosome, Trypanosoma humboldti Morillas et al., 1987, and only one trypanoplasm, Trypanoplasma $(=$ Cryptobia $)$ neghmei Khan et al., 2001,

\begin{abstract}
Two new protistan species were observed in a blenniid fish, Scartichthys viridis, inhabiting tide pools at Las Cruces, central Chile. Trypanoplasma ojedae sp. n. (Mastigophora: Kinetoplastida) in the blood is characterized by its small size $(29.8 \pm 5.0 \times 5.1 \pm 1.2 \mu \mathrm{m})$, short anterior flagellum $(4.9 \pm 0.6 \mu \mathrm{m})$, anterior located kinetoplast $(2.4 \pm$ 0.2 ) and a prominent undulating membrane. All of 18 fish were infected and $67 \%$ were parasitized on the gills by an unidentified piscicolid leech that harbored developing and infective biflagellated stages. Trichodina lascrucensis sp. n. (Ciliophora: Peritrichida) parasitized the gill fillaments of all fish. The ciliate is characterized by its body size $(70.8 \pm 8.4 \mu \mathrm{m})$, adhesive $\operatorname{disc}(53 \pm 5.4 \mu \mathrm{m})$, denticular ring $(33 \pm 3.1 \mu \mathrm{m})$, mean number of denticles $(32.8 \pm 3.0)$, mean number of denticular pins $(9.5$ \pm 1.0 ) and ovoid micronucleus located near to one of the macronuclear arms. Since none of the two parasites was similar to any species described from marine tide pool habitats as well as from the Pacific Ocean, both are considered new species with the characteristics described herein.
\end{abstract}

Key words: Intertidal fish, haemoparasite, gill ciliate, Southeast Pacific

are known from the southeastern Pacific (Morillas et al. 1987, Khan et al. 2001). No reports or descriptions of parasitic ciliates have been published from the southeastern Pacific Ocean.

A recent study reported that $S$. viridis was a host for ten species of parasites, eight metazoans and two protistan (Díaz \& George-Nascimento 2003). The latter included unidentified species of Trypanoplasma (= Cryptobia), a biflagellate that occurred in the blood and a trichodinid ciliate attached to its gill filaments. Comparison of the 
morphology of these two protozoan parasites revealed distinct differences from others described from blenniids or other fish species inhabiting intertidal zones. Scartichthys viridis (Valenciennes 1836) is an abundant blenniid fish species occurring in tide pools (Muñoz \& Ojeda 1997, 2000; Berríos \& Vargas 2004, Pulgar et al. 2005), from Bahía Independencia, Perú, up to Valparaíso, Chile (Chirichigno 1974). This species feeds mainly on green and red algae (Muñoz \& Ojeda 1997, 2000; Berríos \& Vargas 2004), attaining up to $310 \mathrm{~mm}$ in total body length (Muñoz \& Ojeda 2000).

The present study provides evidence that both taxa recorded in $S$. viridis are new species occurring in this fish species from the southeastern Pacific Ocean.

\section{Material and methods}

Scartichthys viridis was collected from tide pools at Las Cruces $\left(33^{\circ} 27^{\prime} \mathrm{S}, 71^{\circ} 37^{\prime} \mathrm{W}\right)$ by seine and held for no longer than one day in the laboratory in flow-through aquaria until examination. A total of 18 specimens were examined. To detect protozoans from the blood, a sample was taken from the caudal vein with a needle and heparinised syringe and thick and thin smears prepared on glass slides from each fish. After drying, the slides were incubated at $56^{\circ} \mathrm{C}$ for 30 minutes. Thin smears were fixed in methanol and all smears stained subsequently with Giemsa's stain (1:20 dilution in phosphate buffer, $\mathrm{pH}$ 7.6) for 45 minutes. Gill smears, three to four from each fish, were also prepared and one from each stained with Klein's 2\% silver nitrate, Feulgen's stain and Heidenhain's hematoxylin. Staining and taxonomic criteria followed those outlined by Lom \& Laird (1969).

\section{Results and discussion}

Trypanoplasma ojedae sp. n. (Mastigophora: Kinetoplastida)

Description is based on Giemsa-stained specimens observed in 10 infected fish. Measurements in im include mean \pm standard deviation $(\mathrm{x} \pm \mathrm{s}$. d., $\mu \mathrm{m})$.

Genus Trypanoplasma Laveran \& Mesnil 1901. Trypanoplasma ojedae sp. n. (Figs. 1a-c, and Fig. 2). Diagnosis: Body slender, elongate $29.8 \pm 5.0$ x $5.0 \pm 1.2$, rounded anteriorly and tapering posteriorly; undulating membrane extending full length of body. Both flagella, longer anterior $(4.9 \pm 0.3)$ and shorter posterior $(3.1 \pm$ 0.2 ), nucleus ovoid $3.9 \pm 0.3$, located $6.0 \mu \mathrm{m}$ from anterior extremity and $3.0 \mu \mathrm{m}$ from kinetoplast; kinetoplast slightly elongates $5.2 \pm 0.4 \times 2.1 \pm 0.2$, located near anterior end.

Development stages in an unidentified piscicolid leech attached to gill filaments (Figs. 1d-g). Ovoid forms, 5.3
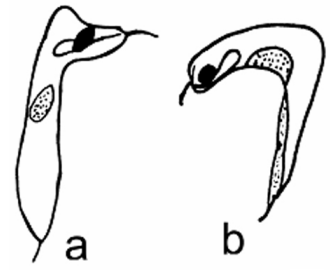

\section{$\overline{10 \mu \mathrm{m}}$}

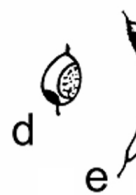

$\overline{5 \mu \mathrm{m}}$

\section{Figure 1}

Line diagrams of Trypanoplasma (= Cryptobia) ojedae sp. $\mathrm{n}$. in the blood of Scartichthys viridis (a-c) and in the crop of an unidentified leech (d-g). Abbreviations: A, aciculum;

$\mathrm{F}$, anterior flagellum; $\mathrm{K}$, kinetoplast, $\mathrm{N}$, nucleus; $\mathrm{U}$, undulating membrane

Diagramas de Trypanoplasma (=Cryptobia) ojedae sp. n. en la sangre de Scartichthys viridis (a-c) y en el cultivo de una sanguijuela no identificada (d-g). Abreviaturas: A, aciculum; F, flagelo anterior; $\mathrm{K}$, kinetoplasto;

$\mathrm{N}$, núcleo; $\mathrm{U}$, membrana ondulante

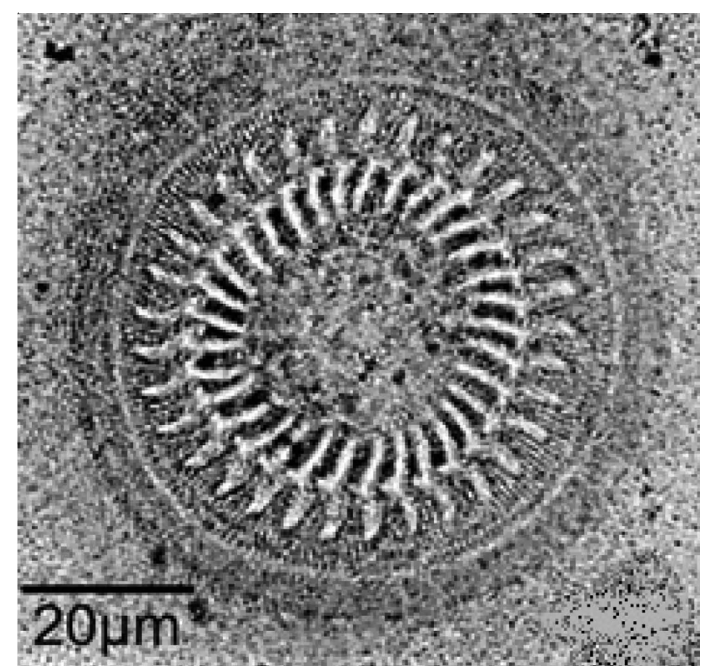

Figure 2

Photomicrograph of Trichodina lascrucensis sp. n. (in silver nitrate preparation) from the gills of Scartichthys viridis

Fotomicrografía de Trichodina lascrucensis sp. n. (en preparación de nitrato de plata) de las branquias de Scartichthys viridis 
\pm 0.3 ; nucleus $2.4 \pm 0.1$; kinetoplast and two flagella visible (Fig. 1d). Elongate forms, body slender, $10.6 \pm$ 0.7 × $2.5 \pm 0.3 \mu \mathrm{m}$; prominent undulating membrane; nucleus elongate $3.2 \pm 0.2 \pm 1.6 \pm 0.1$; kinetoplast ovoid to elongate $2.4 \pm 0.3 \times 1.6 \pm 0.1$; anterior and posterior flagella present but barely visible (Figs. 1e-g).

\section{Taxonomic remarks}

Four species of Trypanoplasma have been described from the blood of marine fish previously, two from the Pacific and one from the Atlantic Ocean (see Burreson 2007). Trypanoplasma beckeri was described from Scorpaenichthys marmoratus in Oregon coastal waters in the North Pacific (Burreson 1979a). The parasite was characterised by an acicular-like process located at its anterior extremity (Table 1) This organelle was not observed in either T. bullocki from Pleuronectes (= Pseudopleuronectes) americanus inhabiting Chesapeake Bay, U.S.A. in the North Atlantic or T. neghmei in Paralichthys spp. off coastal Chile in the South Pacific (Burreson 1979b, Khan et al. 2001). Both species of flagellates, T. beckeri and T. neghmei, infecting fish from the Pacific are considerably larger than $T$. ojedae sp. n. observed in the intertidal fish $S$. viridis from the coast of Chile (Table 1). In addition, the morphology of stages in an unidentified leech-vector possesses a distinct undulating membrane and an organelle resembling an acicular-like process not observed in the other species. We suggest that these differences are adequate to consider
T. ojedae sp. n. distinct from the other species mentioned previously.

\section{Taxonomy summary}

Type host: Scartichthys viridis (Valenciennes 1836).

Geographical location: Coast of Central Chile at Las Cruces, $33^{\circ} 27^{\prime} \mathrm{S}, 71^{\circ} 37^{\prime} \mathrm{W}$.

Site of infection: Blood.

Prevalence: $100 \%$ of 18 fish infected.

Etymology: The species is named after Professor F. Patricio Ojeda for his contributions to fish ecology in Chile.

Deposition of specimens: Holotype deposited in the Museo Nacional de Historia Natural, Santiago, Chile. Catalogue number MNHNCL 3011. Paratypes, catalogue numbers MNHNCL 3012-3016

\section{Trichodina lascrucensis sp. n. (Ciliophora: Peritrichida)}

This new species is described by the following measurements $(\mu \mathrm{m})$ (Figs. 2 and 3 ): body diameter 70.8 \pm 5.1 ; adhesive disc $53.6 \pm 3.4$; denticular ring $33 \pm 3.2$; border membrane $2.2 \pm 0.2$; number of denticles $32.8 \pm$ 1.8; number of radial pins $8.0 \pm 0.4$; length of denticle $11.8 \pm 1.1$; length of blade $3.4 \pm 0.3$; width of blade $3.2 \pm$ 0.3 ; length of thorn $3.2 \pm 0.3$; micronucleus ovoid $2.4 \pm$ 0.1 , located near macronuclear arm $(+y)$; macronucleus horseshoe-shaped, diameter $29.6 \pm 3.1$.

\section{Table 1}

Comparison of morphological characteristics $(\mu \mathrm{m})$ of Trypanoplasma beckeri, T. bobolsoni, T. neghmei y T. ojedae sp. n. from the blood of marine fish from the Pacific Ocean

Comparación de características morfológicas $(\mu \mathrm{m})$ de Trypanoplasma beckeri, T. bobolsoni, T. neghmei and T. ojedae sp. n. de la sangre de peces marinos del Océano Pacífico

\begin{tabular}{lcccc}
\hline & T. beckeri & T. bobolsoni & T. neghmei & T. ojedae sp. $\mathrm{n}$ \\
\hline Body length & $104(43-165)$ & $16.8(13.9-18.8)$ & $41.9 \pm 3.4^{*}$ & $29.8 \pm 3.0(25-34)$ \\
Body width & $6.5(4-11)$ & $3.3(2.5-5.0)$ & $3.8 \pm 0.6$ & $3.1 \pm 0.3(4-6)$ \\
Anterior flagellum & $8.5(7-10)$ & $17.2(14.9-21.5)$ & $10.3 \pm 1.1$ & $4.9 \pm 0.6(4-6)$ \\
Posterior flagellum & $2.5(1-3)$ & $9.0(7.1-10.2)$ & $5.2 \pm 0.4$ & $3.1 \pm 0.3(2-4)$ \\
Nuclear length & $8.5(5-10)$ & $4.9(4.0-5.9)$ & $3.8 \pm 0.2$ & $2.9 \pm 0.3(2-4)$ \\
Nuclear width & $4.0(4-6)$ & $0.8(0.2-1.2)$ & $3.2 \pm 0.1$ & -- \\
Location from anterior & $10.5(6-14)$ & -- & -- & $2.4 \pm 0.2(2-4)$ \\
end & & & & elongate \\
Kinetoplast shape & acicular-like & elongate & & \\
\hline
\end{tabular}

*error in publication; emended 


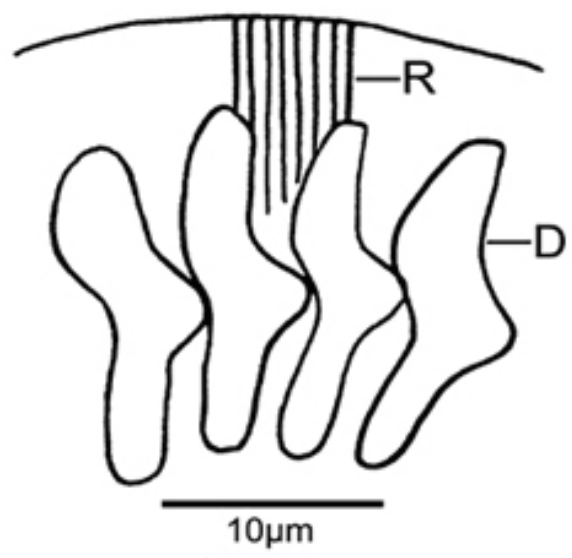

Figure 3

Line diagram of Trichodina lascrucensis sp. n. showing denticles (D) and radial pins (R)

Diagrama de Trichodina lascrucensis sp. n. mostrando dentículos (D) y pins radiales (R)

\section{Taxonomic remarks}

Three species of Trichodina have been reported previously from blenniid fish. Fantham (1930) described T. blennii from the gills of Blennius cornutus from coastal South Africa that was considerably smaller with fewer denticles and radial pins than T. lascrucensis sp. n. (Table 2). Tripathi (1948) reported T. branchicola from eight species of fish, including two blenniids, captured at Plymouth, U.K. The parasite was notably smaller in size than both T. blennii and T. lascrucensis sp. n. (Table 2). A third species, T. multidentis, infected blenniids inhabiting the intertidal zone at Wellington, New Zealand in the Pacific (Laird 1953). Although several of its morphometric characteristics appear similar to those of T. lascrucencis sp. n., the shape of the denticles (Fig. 4), the wide range in size of its adhesive disc and its larger denticular ring separates the two parasites (Table 2). Consequently, we consider T. lascrucensis sp. n. distinct from $T$. multidentis and designate it with the characteristics noted herein.

Trichodina lascrucensis sp. n. is considerably larger than any other trichodinids described from intertidal or subtidal habitats in the northwestern Atlantic (Lom \& Laird 1969). Additionally, the adhesive disc, denticular ring and number of denticles are greater than in $T$. elizabethae, T.jaramilae, T. gahzae, T. domerguei subsp. saintjohnsi and T. cottidarum. The only species occurring in a tide pool fish, the radiated shanny (Ulvaria subbifurcata) is considerably different from $T$. lascrucensis sp. n. (Table 2). In view of a lack of characters to other species described from marine fish, we consider T. lascrucensis as a new species.

Table 2

Comparison of morphometric characteristics $(\mu \mathrm{m})$ of Trichodina blennii, T. branchicola, T. multidentis and T. lascrucensis sp. n. from the blood of marine fish from the Pacific Ocean

Comparación de características morfométricas $(\mu \mathrm{m})$ de Trichodina blennii, T. branchicola, T. multidentis y T. lascrucensis sp. n. de la sangre de peces marinos del Océano Pacífico

\begin{tabular}{lcccc}
\hline & T. blennii & T. branchicola & T. multidentis & T. lascrucensis sp. n. \\
\hline Body diameter & $40-45$ & $30-45$ & $73.3^{\dagger}$ & $70.8 \pm 5.1(60-84)$ \\
Adhesive disc & $24-27$ & $19-23$ & $53.2(25.3-67.5)$ & $53.6 \pm 3.4(48-60)$ \\
Denticular ring & -- & $10-20$ & $34.8(10.8-45.4)$ & $33.0 \pm 3.2(28-40)$ \\
Border membrane & -- & -- & 2 & $2.2 \pm 0.2(2-3)$ \\
Number of denticles & $24-32$ & $20-26$ & $32(23-45)$ & $32.8 \pm 1.1(30-36)$ \\
Number of radial pins & 5 & $6-8$ & $7-9$ & $8.0 \pm 0.4(7-9)$ \\
Length of denticle & -- & -- & $\sim 10^{\ddagger}$ & $11.8 \pm 1.1(10-14)$ \\
Length of blade & -- & -- & $\sim 5.6 \ddagger$ & $3.4 \pm 0.3(3-4)$ \\
Width of blade & -- & -- & $\sim 3.9 \ddagger$ & $3.2 \pm 0.3(2-4)$ \\
Length of thorn & -- & -- & $\sim 3.6 \ddagger$ & $3.2 \pm 0.2(2-4)$ \\
Macronucleus diameter & -- & -- & -- & $29.6 \pm 3.1(26-35)$ \\
\hline
\end{tabular}

†based on figure 88 by Laird (1953); †based on figure 89 by Laird (1953) 


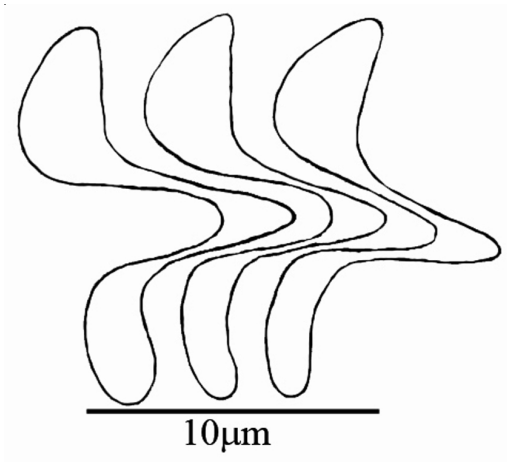

Figure 4

Denticles of $T$. multidentis redrawn from figure 89 in Laird (1953)

Dentículos de T. multidentis redibujado según figura 89 en Laird (1953)

\section{Taxonomic summary}

Type host: Scartichthys viridis (Valenciennes 1836).

Geographical location: coast of central Chile at Las Cruces, $33^{\circ} 27^{\prime} \mathrm{S}, 71^{\circ} 37^{\circ} \mathrm{W}$.

Site of infection: gill filaments.

Prevalence: $100 \%$ of 18 fish infected.

Etymology: The species is named after the location where its infected host occurred.

Deposition of specimens: Holotype deposited in the Museo Nacional de Historia Natural, Santiago, Chile. Catalogue number MNHNCL $\mathrm{N}^{\circ}$ 3008. Paratypes, catalogue numbers MNHNCL No $3009-3010$.

\section{Acknowledgments}

The authors are grateful for financial support from FONDECYT 1980442 and FONDAP Program 3, Marine Biology and Conservation (to MG-N), the Natural Sciences and Engineering Council of Canada (to RAK), Mr. R. Finken for preparing the figures and to Ms. S. Wall for typing the manuscript. Critical comments made by three referees helped to improve the manuscript and are also acknowledged.

\section{Literature cited}

Berríos V \& M Vargas. 2004. Estructura trófica de la asociación de peces intermareales de la costa rocosa del norte de Chile. Revista Chilena de Historia Natural 52: 201212.

Burreson EM. 1979a. Structure and life cycle of Trypanoplasma beckeri sp. n. (Kinetoplastida), a parasite of the cabezon, Scorpaenichthys marmoratus, in Oregon coastal waters. Journal of Protozoology 26: 343-347.
Burreson EM. 1979b. The life cycle of Trypanoplasma bullocki (Zoomastigophorea: Kinetoplastida). Journal of Protozoology 29: 72-77.

Burreson EM. 2007. Hemoflagellates of Oregon marine fishes with the description of new species of Trypanosoma and Trypanoplasma. Journal of Parasitology 93: 1442-1451.

Castro R \& R Burgos. 1996. Kudoa thyrsites (Myxozoa, Multivalvulida) causing "milky condition» in the musculature of Paralichthys adspersus (Neopterygii, Pleuronectiformes, Paralichthyidae) from Chile. Memorias do Instituto Oswaldo Cruz 91: 163-164.

Chirichigno N. 1974. Clave para identificar los peces marinos del Perú. Instituto del Mar del Perú, Callao. Informe 44: 1387.

Díaz F \& M George-Nascimento. 2003. Estabilidad temporal de las infracomunidades de parásitos en la borrachilla Scartichthys viridis (Valenciennes, 1836) (Pisces: Blenniidae) en la costa central de Chile. Revista Chilena de Historia Natural 75: 641-649.

Fantham HB. 1930. Some parasitic Protozoa found in South Africa, XIII. South African Journal of Science 27: 376390.

George-Nascimento M, V Lobos, C Torrijos \& R Khan. 2004. Species composition of assemblages of Ceratomyxa (Myxozoa), parasites of lings Genypterus (Ophidiidae) in the Southeastern Pacific Ocean: an ecomorphometric approach. Journal of Parasitology 90: 1352-1355.

Ibáñez C, MC Pardo-Gandarillas, M George-Nascimento. 2005. Uso del microhábitat por el protozoo parásito Aggregata patagonica Sardella, Ré \& Timi, 2000 (Apicomplexa: Aggregatidae) en su hospedador definitivo, el pulpo Enteroctopus megalocyathus (Gould, 1852) (Cephalopoda: Octopodidae) en el sur de Chile. Revista Chilena de Historia Natural 78: 441-450.

Khan R, V Lobos, F Garcías, G Muñoz, V Valdebenito \& M George-Nascimento. 2001. Cryptobia neghmei sp. n. (Protozoa: Kinetoplastida) in two species of flounder, Paralichthys spp. (Pisces: Paralichthydae) off Chile. Revista Chilena de Historia Natural 74: 763-767.

Laird M. 1953. The protozoa of New Zealand intertidal zone fishes. Transactions of the Royal Society of New Zealand 81: 79-143.

Lom J \& I Dykova. 1992. Protozoan parasites of fishes, 315 pp. Elsevier, Amsterdam.

Lom J \& M Laird. 1969. Parasitic protozoa from marine and euryhaline fish of Newfoundland and New Brunswick. I. Peritrichous ciliates. Canadian Journal of Zoology 47: 1367-1380.

Morillas J, M George-Nascimento, H Valeria \& RA Khan. 1987. Trypanosoma humboldti $\mathrm{n}$. sp. from the Chilean catshark, Schroederichthys chilensis (Guichenot, 1848). Journal of Protozoology 34: 3342-344. 
Moser M \& ER Noble. 1976. The genus Ceratomyxa (Protozoa: Myxosporida) in macrourid fishes. Canadian Journal of Zoology 54: 1535-1537.

Muñoz A \& FP Ojeda. 1997. Feeding guild structure of a rocky intertidal fish assemblage in central Chile. Environmental Biology of Fishes 49: 471-479.

Muñoz A \& FP Ojeda. 2000. Ontogenetic changes in the diet of the herbivorous Scartichthys viridis in a rocky intertidal zone in central Chile. Journal of Fish Biology 56: 986-998

Oliva ME. 1982. Parásitos en peces marinos de la zona de Antofagasta. Ciencia y Tecnología del Mar 6: 45-51.

Pardo-Gandarillas MC, F Garcías \& M George-Nascimento. 2004. La dieta y la fauna de parásitos del pejesapo Gobiesox marmoratus Jenyns, 1842 (Pisces: Gobiesocidae) en el litoral centro - sur de Chile: dos procesos concatenados pero no correlacionados. Revista Chilena de Historia Natural 77: 627-637.
Pardo-Gandarillas MC, K González, CM Ibáñez \& M GeorgeNascimento. 2007. Parasites of two deep-sea fishes Coelorynchus chilensis (Pisces: Macrouridae) and Notacanthus sexspinis (Pisces: Notacanthidae) from Juan Fernández Archipelago, Chile. JMBA2. Biodiversity Records. http://www.mba.ac.uk/jmba/biodiversityrecords . php ? jmbaref= 5794 [on-line].

Pulgar JM, F Bozinovic \& FP Ojeda. 2005. Local distribution and thermal ecology of two intertidal fishes. Oecologia 142: 511-520.

Tripathi YR. 1948. A new species of ciliate, Trichodina branchicola, from some fishes at Plymouth. Journal of the Marine Biological Association of the United Kingdom 27: $440-450$

Recibido el 5 de marzo de 2008 y aceptado el 3 de octubre de 2008 